\title{
Nutritional and Phenolic composition of Morinda citrifolia L. (Noni) fruit at different ripeness stages and seasonal patterns harvested in Nayarit, Mexico
}

\author{
Lewis Luján, Lidianys María*; Iloki Assanga, Simon Bernard; Rivera-Castañeda, Elba Griselda; \\ Gil- Salido, Armida Andrea; Acosta-Silva, Ana Lilian; Meza-Cueto, Cipactli Yuridia; \\ Rubio-Pino, José Luis
}

Rubio Pharma y Asociados S. A de C. V., Laboratorio de Investigaciones en Bioactivos y Alimentos Funcionales (LIBAF), Hermosillo, Sonora, México

\section{Email address:}

lidianyslewis@rubiopharma.com (L. M. L. Luján), lidianys1@yahoo.es (L. M. L. Luján), andreagil@libaf.com (A. A. Gil-Salido), drsimoniloki@rubiopharma.com (Simon B. I. A.), griseldarivera@libaf.com (E. G. Rivera-Castañeda), analilianacosta@libaf.com (A. L. Acosta-Silva), cipactliyuridiameza@libaf.com (C. Y. Meza-Cueto), medicinabiologica@rubiopharma.com (J. L. Rubio-Pino)

\section{To cite this article:}

Lewis Luján, Lidianys María; Iloki Assanga, Simon Bernard; Rivera-Castañeda, Elba Griselda; Gil- Salido, Armida Andrea; Acosta-Silva, Ana Lilian; Meza-Cueto, Cipactli Yuridia; Rubio-Pino, José Luis. Nutritional and Phenolic Composition of Morinda Citrifolia L. (Noni) Fruit at Different Ripeness Stages and Seasonal Patterns Harvested in Nayarit, Mexico. International Journal of Nutrition and Food Sciences. Vol. 3, No. 5, 2014, pp. 421-429. doi: 10.11648/j.ijnfs.20140305.19

\begin{abstract}
Morinda citrifolia L. (Noni) fruit harvested in Tepic, Nayarit, Mexico presented alterations in its composition and its properties with the process of senescence during ripening and the seasons of harvest.. Various stages of maturity (stages 1-4) were examined for their physico-chemical properties (moisture, soluble protein, total carbohydrates, titratable acidity, pH, soluble solids, ash, vitamin $\mathrm{C}$, and phenolic compounds). Generally maturation increased moisture, soluble protein, total carbohydrates, total acidity, vitamin C, and phenolic compounds. During May-June noni fruits (stages 1-4) had the highest levels of soluble protein (8.73-15.63 g/100 g FW), total carbohydrates (6.60-9.60 g/100g FW), ash (0.87$1.34 \mathrm{~g} / 100 \mathrm{~g} \mathrm{FW})$, ascorbic acid (115.85-182.42 mg/100 g FW) and total phenols (3022.8-3647.0 $\mu \mathrm{g} / \mathrm{g}$ FW). Middle stage (stage 2) and ripe soft noni fruits (stage 4) had greater total phenolic and rutin (47.18-69.88 $\mu \mathrm{g} / \mathrm{g}$ FW-stage 2 and $65.22-$ $81.34 \mu \mathrm{g} / \mathrm{g}$ FW-stage 4); this profile appears to be independent of season.
\end{abstract}

Keywords: Noni, Composition, Vitamin C, Phenolic Compound, Ripening Stage, Seasons Harvest

\section{Introduction}

Morinda citrifolia L., Rubiaceae is a tropical and subtropical plant grown in the Pacific islands; it has been used traditionally as a folk medicine to treat a broad range of diseases for over 2000 years [1]. Noni is native to Southeast Asia and Australia, and is cultivated in Polynesia, India, the Caribbean, Central and northern South America [2].

Biological compounds such as glycosides, polysaccharides, phenolic compounds, alkaloids, lignans, fatty acid esters, organic acids, vitamins and minerals have been isolated from noni fruits, roots, and leaves [3, 4, 5]. Of the phenolic compounds, the most important reported are anthraquinones: damnacanthal, morindone, morindin, etc, and also aucubin, asperuloside, rutin and scopoletin $[5,6]$.

The complete physic-chemical composition of the fruit according to maturity stages and seasonal patterns has not yet been reported and only partial information is available on noni juice. However, chemical composition varies widely according to the part of the plant. The fruit contains $90 \%$ water, and the main components of the dry matter appear to be soluble solids, dietary fibers and proteins [7]. Minerals mainly potassium, sulfur, calcium, phosphorus and traces of selenium have been reported in the juice [7]. Vitamins have been reported in the fruit, mainly ascorbic acid (25-158 mg/100 g dry matter) $[6,8]$ and pro-vitamin A. The main volatile compounds have been identified in the ripe fruit including organic acids (mainly caproic, caprylic, 
octanoic and hexanoic acids), alcohols (3 methyl 3-buten-1ol), esters (methyl octanoate, methyl decanoate), ketones (2-heptanone), and lactones (E-6-dodeceno- $\gamma$-lactone) [9].

Morinda citrifolia is a perennial bush and it is possible to find fruits at different stages of maturity on the same plant at the same time. The fruits may be harvested at different stages of development and continue to mature. The color and firmness of fruits left to ripen naturally on the tree evolves from dark green-very hard to translucent-grayish, soft [1]. During ripening, the composition and textural properties change with the senescence process. These composition factors and textural properties are part of the quality of the fruits and of their selection [10].

The quality and quantity of the chemical and nutritional components contained in plants are directly related to the soil, climate and geographical location [11].

In Mexico noni fruits are harvested throughout the year, although there are seasonal patterns in flowering and fruit bearing. In the last five years, the production and growing areas have been increased. The distribution is located mainly in the states of Nayarit, Michoacán, Tabasco, Jalisco and Yucatan [12].

The main aim of this study was to evaluate the nutritional and chemical composition at various degrees of maturity in different seasonal patterns of noni fruit from San Blas, Nayarit, Mexico, to understand these changes during the ripening process. We characterized noni fruit from San Blas, Nayarit, Mexico harvested in different seasonal patterns according to different stages of maturity; this is the first analysis of noni fruit from Nayarit. This information is required for the achievement the definition of the quality standard of the product and the specifications of the production system.

\section{Materials and Methods}

\subsection{Noni Harvest and Sampling}

The noni fruits at different ripening stages were harvested from agricultural cooperative societies, in San Blas, Nayarit, Mexico (latitude 21.4167, longitude: 105.1833, altitude: $30 \mathrm{~m}$ a.s.1.). Fruits were harvested from one farm with soils representing mainly four orders (Luvisol (38.7\%), Solonchak (15.1\%), Cambisol (14.8\%) and Phaeozem $(10.1 \%))$. Noni grow under conventional and organic agricultural practice.

Three independent sampling were carried out at the beginning, mid-point and at the end of February-March (winter-spring); May-June (spring-summer); and November (autumn) 2010 for ensure the reliability of data.

The minimum and maximum temperatures as follows: February-March, 11.1 to $32.0{ }^{\circ} \mathrm{C}$; May-June, 15.8 to $33.7{ }^{\circ} \mathrm{C}$; and November, 11.7 to $35.2^{\circ} \mathrm{C}$. Maximum light intensity during winter-spring months of February to March was 1123.3 $\mu_{\mathrm{molm}} \mathrm{s}^{-1}$, in the spring-summer months was $1182.9 \mu \mathrm{molm}^{-2} \mathrm{~s}^{-1}$, and while in autumn (November) maximum light intensity was $982.2 \mu \mathrm{molm}^{-2} \mathrm{~s}^{-1}$. Rainfall in
San Blas are favorable for the development of agriculture, in 2010 the range of rainfall was $1300-2000 \mathrm{~mm}$ [13].

The fruits sampling was standardized under the following condition: trees were randomly selected and approximately 60-70 fruits were collected from different parts of the tree. Fruits were classified in four maturity stages according to the size, external color and firmness. A photographic catalogue provided previously at personnel of cooperative societies, was used to accomplish this goal.

The fruits were placed in polyethylene bags and transported under refrigerated conditions to the laboratory. Before performing the analyses, the whole fruits were washed under running tap water and distilled water to remove dirt and other foreign materials and dried at room temperature. The fruits were classified in four groups according to maturity stages (Table 1). To each group of approximately $10-15$ pieces, three independent samples of at least 3 injury-free noni fruits were selected at random and all inedible parts were removed using a steel knife. The groups of fruits at different ripeness stages were chopped and homogenized in a high-speed blender (Osterizer professional model, USA) for $1 \mathrm{~min}$. Samples were then immediately analyzed for soluble solids content, total titratable acidity, $\mathrm{pH}$, and total vitamin $\mathrm{C}$ content. Chemical analysis was completed within 2 weeks of storage at $-20^{\circ} \mathrm{C}$. About $100 \mathrm{~g}$ of fruit samples were lyophilized for $72 \mathrm{~h}$ in a freeze-drying apparatus (Labconco model free zone 2.5, Kansas City, USA).

The analyses of fruit characteristics were carried out in three independent samples (pulp homogenate), each one analyzed in triplicate.

Table 1. Evolution of fruit color and firmness in the course of ripening.

\begin{tabular}{lll}
\hline Maturity stages & Color & Firmness \\
\hline 1 & Dark green & Very hard \\
2 & Green-yellow & Very hard \\
3 & Pale-yellow & Fairly hard \\
4 & Translucent- grayish & Soft \\
\hline
\end{tabular}

\subsection{Analytical Determinations}

\subsubsection{Titratable Acidity, $\mathrm{pH}$ and Soluble Solids Content}

Titratable acidity was determined by blending a $5 \mathrm{~g}$ of fresh pulp (Ultra-Turrax-IKA T18, Germany) with $50 \mathrm{~mL}$ distilled water for $2 \mathrm{~min}$ at $15,000 \mathrm{rpm}$ to produce a homogeneous slurry and centrifuged at $4205 \mathrm{~g}$ for $10 \mathrm{~min}$ at $4^{\circ} \mathrm{C}$ (HERMLE mod $236 \mathrm{HK}$, Germany). A sample of 2 $\mathrm{mL}$ of the filtered was titrated with $0.1 \mathrm{~mol} / \mathrm{L}$ sodium hydroxide solution (phenolphthalein as indicator). Results were expressed in grams of malic acid per $100 \mathrm{~mL}$ of sample [14].

$\mathrm{pH}$ was measured with a digital $\mathrm{pH}$ meter (Thermo model Orion 710 A PLUS, USA) with application of the electrode directly in to the blended pulp [14].

Soluble solids content was determined using a digital refractometer (ATAGO, Japan) calibrated with $10 \%$ sucrose. A few drop of squeezing the pulp into the prism was read as ${ }^{\circ}$ Brix [14]. Triplicates analyses were carried out on all the 
samples.

\subsubsection{Moisture, Ash, Total Carbohydrates and Soluble Protein Content}

Moisture was determined by drying a representative $2 \mathrm{~g}$ of small pieces of fruits in an oven (Felisa, Mexico) with air circulation at $100-105{ }^{\circ} \mathrm{C}$ until constant weight. Results were expressed in percentage [14]. Ash was determined according to the procedure of AOAC [14] by incineration of a representative $0.5 \mathrm{~g}$ dried sample in a muffle furnace at $550{ }^{\circ} \mathrm{C}$ for $8 \mathrm{~h}$. Results were expressed in $\mathrm{g} / 100 \mathrm{~g}$ of fresh weight $(\mathrm{FW})$. The total carbohydrates were determined by phenol sulfuric acid assay with some modifications [15]. Five grams of pulp homogenized were mixed in vortex with $50 \mathrm{~mL}$ distilled water. At $200 \mu \mathrm{L}$ of sample diluted were added $200 \mu \mathrm{L}$ of $5 \%$ aqueous phenol and $1 \mathrm{~mL}$ of concentrated sulfuric acid and was mixed thoroughly. The mixture was allowed to cool to room temperature, and absorbance was measured at $490 \mathrm{~nm}$ in a spectrometer (Cary UV-visible of VARIAN, Australia). D-glucose (20$240 \mu \mathrm{g} / \mathrm{mL}$ ) was used to produce standard calibration curve. Results were expressed in $\mathrm{g} / 100 \mathrm{~g}$ of fresh weight (FW). Soluble protein was quantified with the Lowry method [16]. A $250 \mu \mathrm{L}$ of homogenates at five concentrations (0.5-1.5 $\mathrm{mg} / \mathrm{mL}$ ) was mixed with $250 \mu \mathrm{L}$ of distilled water and 1.25 $\mathrm{mL}$ of $1 \%$ of cupric sulfate, 5 -hydrate and $2 \%$ potassium sodium tartrate $1: 1(\mathrm{v} / \mathrm{v})$. The plate was incubated at room temperature for $15 \mathrm{~min}$. Then, $125 \mu \mathrm{L}$ of $1: 4$ FolinCiocalteu reagent: water solution was added to the mixture and incubated at room temperature for $30 \mathrm{~min}$. Absorbance was determined at $580 \mathrm{~nm}$ versus reactive blank with a microplate spectrophotometer reader (Thermo Scientific, Finland). Soluble protein content was calculated using bovine serum albumin (Sigma-Aldrich CO., USA) as standard at five different concentrations, in the range of $0.2-1 \mathrm{mg} / \mathrm{mL}\left(\mathrm{R}^{2}=0.996\right)$ in triplicate. The results were expressed in $\mathrm{g} / 100 \mathrm{~g}$ of $\mathrm{FW}$.

The inter- and intra-day variability of each analytical method was measured repeating the analyses three times on the same day and tree times on three alternate days using the grayish-soft-ripe stage homogenate of noni fruit as sample. The coefficients of variation of the intra-day and the inter-day variability were calculated to be below $5 \%$ and $7 \%$, respectively, for the analytical methods.

\subsubsection{Determination of Ascorbic Acid Content (AA), Total Phenol and Phenolic Compounds}

The AA determinations were based on the method described by [17] with some modifications. For extraction, the mixture was prepared with $1 \mathrm{~g}$ of fruit pulp and $10 \mathrm{~mL}$ of methaphosporic acid and acetic acid. The solution was shaken slightly for 30 minutes in absence of light, and then centrifuged at $4205 \mathrm{~g}$ for $5 \mathrm{~min}$ (HERMLE mod 236HK, Germany). The supernatant was filtered through a $0.22 \mu \mathrm{m}$ nylon filter (Millipore) and stored at $-20{ }^{\circ} \mathrm{C}$ for later analysis. $20 \mu \mathrm{l}$ were injected into HPLC system that consisted in a (Varian ProStar model 240 solvent delivery module, Australia) and a Varian Prostar 325 UV-Vis detector with Galaxie version 1.9 software. The separation was performed on a reverse-phase C-18 analytical column (Varian Microsorb 100, $5 \mu \mathrm{M}, 4.6 \times 150 \mathrm{~mm}$ ) coupled with a C-18 guard cartridge $(5 \mu \mathrm{M}, 4.3 \times 10 \mathrm{~mm})$ at room temperature. An isocratic method was used, with $\mathrm{KH}_{2} \mathrm{PO}_{4}$ $(0.05 \mathrm{~N})$ : acetonitrile: $(99: 1 \mathrm{v} / \mathrm{v})$ as the mobile phase at a flow rate of $1.0 \mathrm{~mL} / \mathrm{min}$. Acid ascorbic was detected by UV at $268 \mathrm{~nm}$. The concentrations of AA were calculated using a standard curve and the results were expressed in $\mathrm{mg} / 100$ $\mathrm{g}$ of fresh weight (FW).

Linearity range was studied with 5 triplicate points between $50-250 \mu \mathrm{g} / \mathrm{mL}\left(\mathrm{R}^{2}=0.998\right)$. The same calibration runs were used for the limits of detection, considered as the concentration three times higher than the noise.

Repeatability of the method was carried out by five injections of ascorbic acid standard, and by calculating the standard deviation of each analyze concentration.

Accuracy was assessed at three different concentration levels of ascorbic acid standard by replicate measurements $(n=3)$. In order to determine the accuracy of the method, three random samples were spiked with known amount of the standard compound, processed under same conditions and analyzed using the specified HPLC method. The recovery rate was between $93 \%$ and $98 \%$.

Total polyphenols content was determined by the FolinCiocalteu method [18] with light modification. About $1 \mathrm{~g}$ of pulp was homogenized and extracted with $10 \mathrm{~mL}$ distilled water for $2 \mathrm{~min}$ at $15,000 \mathrm{rpm}$ (Ultra-Turrax IKA T-18, Germany) at ambient temperature. The homogenate was centrifuged at $4205 \mathrm{~g}$ for $5 \mathrm{~min}$ (HERMLE mod 236HK, Germany). A $0.5 \mathrm{~mL}$ aliquot of the supernatant was added to $0.5 \mathrm{~mL}$ of $1: 4$ Folin-Ciocalteu reagent: water solution. The plate was allowed to stand at room temperature for 1 min. Then, $0.5 \mathrm{~mL}$ of $10 \%(\mathrm{w} / \mathrm{v}) \mathrm{Na}_{2} \mathrm{CO}_{3}$ was added to the mixture. After $2 \mathrm{~h}$ at room temperature, absorbance of the samples was measured at $765 \mathrm{~nm}$ versus a blank in a microplate spectrophotometer reader (Thermo Scientific, Finland). The results were expressed as $\mu \mathrm{g}$ gallic acid equivalent $(\mathrm{GAE}) / \mathrm{g}$ fresh weight $(\mathrm{FW})$. Calibration was performed by analyzing the standard gallic acid (SigmaAldrich CO., USA) three times at five different concentrations, in the range of $6.25-100 \mu \mathrm{g} / \mathrm{mL}\left(\mathrm{R}^{2}=0.999\right)$.

The extraction and HPLC analysis for phenolic compounds was modified from [19]. One gram of fresh pulp was mixed with $10 \mathrm{~mL}$ of ethyl acetate; the mixture was shaken slightly for 30 minutes and then centrifuged at $4205 \mathrm{~g}$ for $5 \mathrm{~min}$ (HERMLE mod 236HK, Germany). The supernatant was removed and the extraction process was repeated twice. The combined filtrates were evaporated to dryness under vacuum using a rotatory evaporator (Buchi, Switzerland) and reconstituted in $2 \mathrm{~mL}$ of methanol: water $(50: 50 \mathrm{v} / \mathrm{v})$. Finally, the extracts were filtered through a 0.22 $\mu \mathrm{m}$ nylon filter (Millipore) and stored at $-20{ }^{\circ} \mathrm{C}$ until analysis. HPLC was performed on a Varian 240 using a detection wavelength of $280 \mathrm{~nm}$, a flow rate of $1 \mathrm{~mL} / \mathrm{min}$, a sample size of $20 \mu \mathrm{l}$, and at a column C-18 (Varian Microsorb 100, 5 $\mu \mathrm{M}, 4.6 \times 150 \mathrm{~mm})$ coupled with a $\mathrm{C}-18$ guard cartridge 
(Varian, $5 \mu \mathrm{M}, 4.3 \times 10 \mathrm{~mm}$ ), with mobile phase A (Acetic acid: water $2 \% \mathrm{v} / \mathrm{v}$ ) and B (methanol) in gradient. Gallic acid, catechin, scopoletin, rutin and quercetin standards were injected for identification of these compounds in the samples by comparison of retention times.

Calibration was performed by injecting the standards three times at five different concentrations, in the range of 50-200 $\mu \mathrm{g} / \mathrm{mL}$. The peak areas versus concentrations were calibrated using a linear least-square analysis. External standards were gallic acid (97.9\% purity, $\left.\mathrm{R}^{2}=0.997\right) ;(+)$-catechin $(100 \%$ purity, $\left.\mathrm{R}^{2}=0.999\right)$; scopoletin $\left(100 \%\right.$ purity, $\left.\mathrm{R}^{2}=0.999\right)$; rutin $\left(96 \%, R^{2}=0.999\right)$ and quercetin ( $98 \%$ purity, $\left.\mathrm{R}^{2}=0.999\right)$, all from Sigma-Aldrich CO., USA. Compounds were identified by comparison of their retention times of the peaks detected with those of the corresponding standards. Quantifications of noni samples were performed from the peak area of each component and its corresponding calibration curve. The contents of phenolic compounds were expressed in $\mu \mathrm{g}$ per $\mathrm{g}$ fresh weight.

Recovery evaluations were performed by phenolics standards mixture in absolute methanol at $1 \mathrm{mg} / \mathrm{mL}$. An aliquot of standards mixture was added in three random samples processed under same conditions and analyzed using the specified phenolic compounds HPLC method. The recovery rates were between $99.1-104.5 \% ; 100.1-104.6 \%$ and $93.8-103.8 \%$ for catechin, scopoletin and rutin respectively.

\subsection{Statistical Analysis}

Experiment for ripeness stages effects was carried out using a completely randomized design, with 12 treatments arranged in $4 \times 3$ factorial scheme (four ripeness stages and three harvest seasons) and three replicates. Data were submitted to multifactorial analysis of the variance
(ANOVA); statistical significance and linear regression were performed using NCSS, 2007 software. $P$ values $<0.05$ were regarded as significant by Tukey-Kramer Multiple Comparison test. Correlations were done using Pearson's correlation coefficient (r). Experimental results are expressed as the mean $\pm \mathrm{SD}$ (standard deviation) of three independent sampling with three independent samples in triplicate.

\section{Results and Discussion}

\subsection{Physico-Chemical Determinations}

The results and statistical analysis concerning to the effect of the maturation stage and seasonal patterns on chemical composition are presented in Table 2-3.

Moisture content of all analyzed fruits is given in table 2 . The $\%$ of moisture changed with the progress of maturation and growing season. It ranges from $80.9 \%$ in complete ripening (stage 4) harvested in May-June to $90.8 \%$ in the same stage but collected in February-March. In FebruaryMarch and November, the fruits that were completely ripe demonstrated statistically higher level of water than those totally green. In May-June this behavior was not observed, differing significantly in stages 3-4 with respect to winterspring and autumn, probably owing to greater water loss in this season. Marked variation in the moisture content was observed for unripe-green fruit (stage-1) and full ripe (stage-4) for all season. A loss of 10\% moisture in full ripe noni was found in hot season (May-June), but the behavior was not the same for immature fruits, no differences were found for these stages among seasons. Environmental conditions have vital influence on the samples moisture , which depends on maturity stage.

Table 2. Chemical composition at different ripeness stages and seasons of noni fresh weight (FW).

\begin{tabular}{|c|c|c|c|c|c|}
\hline Maturity Stage & Moisture (\%) & Soluble protein $(\mathrm{g} / 100 \mathrm{~g})$ & Total (g/100 g) carbohydrates & $\operatorname{Ash}(g / 100 g)$ & Ascorbic Acid (mg/ 100g) \\
\hline \multicolumn{6}{|c|}{ February - March (winter - spring) } \\
\hline 1 & $85.9 \pm 0.4^{\mathrm{a}}$ & ${ }^{\mathrm{A}} 6.32 \pm 0.5^{\mathrm{b}}$ & ${ }^{\mathrm{B}} 4.58 \pm 0.1$ & $1.01 \pm 0.04$ & ${ }^{\mathrm{B}} 119 \pm 2.9^{\mathrm{b}}$ \\
\hline 2 & $87.8 \pm 1.1^{\mathrm{ab}}$ & ${ }^{\mathrm{A}} 7.80 \pm 0.2^{\mathrm{b}}$ & ${ }^{\mathrm{B}} 4.75 \pm 0.7$ & $0.79 \pm 0.04$ & ${ }^{\mathrm{B}} 106 \pm 1.5^{\mathrm{c}}$ \\
\hline 3 & ${ }^{\mathrm{B}} 88.0 \pm 0.4^{\mathrm{ab}}$ & ${ }^{\mathrm{A}} 6.98 \pm 0.2^{\mathrm{b}}$ & ${ }^{\mathrm{B}} 4.75 \pm 0.7$ & $0.85 \pm 0.03$ & $126 \pm 6.8^{b}$ \\
\hline 4 & ${ }^{\mathrm{B}} 90.8 \pm 0.2^{\mathrm{b}}$ & $10.3 \pm 1.4^{\mathrm{a}}$ & ${ }^{\mathrm{B}} 4.83 \pm 0.1$ & $0.92 \pm 0.01$ & ${ }^{\mathrm{B}} 180 \pm 1.2^{\mathrm{a}}$ \\
\hline \multicolumn{6}{|c|}{ May -June (spring - summer) } \\
\hline 1 & $85.1 \pm 0.6^{\mathrm{a}}$ & ${ }^{\mathrm{B}} 13.6 \pm 0.5^{\mathrm{b}}$ & ${ }^{\mathrm{c}} 6.60 \pm 0.6^{\mathrm{a}}$ & $0.87 \pm 0.04$ & ${ }^{\mathrm{B}} 116 \pm 0.8^{\mathrm{b}}$ \\
\hline 2 & $85.5 \pm 0.5^{\mathrm{a}}$ & ${ }^{\mathrm{B}} 15.6 \pm 0.0^{\mathrm{a}}$ & ${ }^{\mathrm{c}} 6.70 \pm 0.4^{\mathrm{a}}$ & $1.06 \pm 0.06$ & ${ }^{\mathrm{C}} 140 \pm 13.4^{\mathrm{b}}$ \\
\hline 3 & ${ }^{\mathrm{A}} 84.1 \pm 1.0^{\mathrm{a}}$ & ${ }^{\mathrm{B}} 12.3 \pm 0.0^{\mathrm{b}}$ & ${ }^{\mathrm{C}} 7.20 \pm 0.0^{\mathrm{a}}$ & $0.88 \pm 0.05$ & $156 \pm 4.5^{\mathrm{b}}$ \\
\hline 4 & ${ }^{\mathrm{A}} 80.9 \pm 0.9^{\mathrm{b}}$ & $8.73 \pm 0.1^{\mathrm{c}}$ & ${ }^{\mathrm{c}} 9.60 \pm 0.0^{\mathrm{b}}$ & $1.34 \pm 0.04$ & ${ }^{\mathrm{B}} 182 \pm 2.1^{\mathrm{a}}$ \\
\hline \multicolumn{6}{|c|}{ November (autumn) } \\
\hline 1 & $85.6 \pm 1.4^{\mathrm{a}}$ & ${ }^{\mathrm{A}} 5.96 \pm 0.2^{\mathrm{b}}$ & ${ }^{\mathrm{A}} 2.53 \pm 0.23^{\mathrm{a}}$ & $0.83 \pm 0.05$ & ${ }^{\mathrm{A}} 100 \pm 5.6^{\mathrm{a}}$ \\
\hline 2 & $87.2 \pm 0.7^{\mathrm{ab}}$ & ${ }^{\mathrm{A}} 6.57 \pm 0.3^{\mathrm{b}}$ & ${ }^{\mathrm{A}} 2.20 \pm 0.28^{\mathrm{a}}$ & $0.89 \pm 0.18$ & ${ }^{\mathrm{A}} 76.6 \pm 1.3^{\mathrm{a}}$ \\
\hline 3 & ${ }^{\mathrm{B}} 87.3 \pm 1.0^{\mathrm{ab}}$ & ${ }^{\mathrm{A}} 5.98 \pm 0.4^{\mathrm{b}}$ & ${ }^{\mathrm{A}} 3.60 \pm 0.35^{\mathrm{b}}$ & $0.85 \pm 0.14$ & $129 \pm 11.2^{b}$ \\
\hline 4 & ${ }^{\mathrm{B}} 89.6 \pm 0.7^{\mathrm{b}}$ & $8.22 \pm 0.3^{\mathrm{a}}$ & ${ }^{\mathrm{A}} 3.46 \pm 0.23^{\mathrm{b}}$ & $0.83 \pm 0.00$ & ${ }^{\mathrm{A}} 126 \pm 1.6^{\mathrm{b}}$ \\
\hline
\end{tabular}

Values are given as mean of three independent sampling each one with three replicates in triplicates $(n=9)( \pm S D)$. Means with different lower case letters in the same column indicate significant differences between ripening stages in the same season at $\mathrm{P}<0.05$ by Tukey-Kramer test. Means with different capital letter in the same column are significantly different, in the same maturity stage but in different season at $\mathrm{P}<0.05$, Tukey - Kramer test. 
Table 3. Titratable acid levels (TA), pH, Soluble Solids (S.S), and Total Phenols contents at different maturity stage and seasons.

\begin{tabular}{|c|c|c|c|c|}
\hline Stages & TA (g malic acid/100mL) & $\mathbf{p H}$ & S.S $\left({ }^{0}\right.$ Brix $)$ & Total Phenols ( $\mu \mathrm{g}$ GAE /g FW ${ }^{\mathrm{a}}$ ) \\
\hline \multicolumn{5}{|c|}{ February - March (winter - spring) } \\
\hline 1 & ${ }^{\mathrm{B}} 0.08 \pm 0.03^{\mathrm{a}}$ & ${ }^{\mathrm{A}} 4.56 \pm 0.08^{\mathrm{a}}$ & $8.2 \pm 0.2$ & ${ }^{\mathrm{B}} 2596.8 \pm 240.6^{\mathrm{b}}$ \\
\hline 2 & ${ }^{\mathrm{B}} 0.08 \pm 0.03^{\mathrm{a}}$ & ${ }^{\mathrm{A}} 4.57 \pm 0.03^{\mathrm{a}}$ & ${ }^{\mathrm{B}} 8.4 \pm 0.0$ & ${ }^{\mathrm{B}} 2930.6 \pm 177.5^{\mathrm{a}}$ \\
\hline 3 & ${ }^{\mathrm{B}} 0.14 \pm 0.04^{\mathrm{a}}$ & $4.28 \pm 0.04^{b}$ & ${ }^{\mathrm{A}} 8.6 \pm 0.5$ & $2372.2 \pm 167.3^{b}$ \\
\hline 4 & ${ }^{\mathrm{B}} 0.19 \pm 0.04^{\mathrm{b}}$ & ${ }^{\mathrm{A}} 4.14 \pm 0.04^{\mathrm{b}}$ & ${ }^{\mathrm{A}} 9.3 \pm 0.2$ & $3099.9 \pm 250.2^{\mathrm{a}}$ \\
\hline \multicolumn{5}{|c|}{ May -June (spring - summer) } \\
\hline 1 & ${ }^{\mathrm{B}} 0.06 \pm 0.004^{\mathrm{a}}$ & ${ }^{\mathrm{A}} 4.65 \pm 0.05^{\mathrm{a}}$ & $8.1 \pm 0.9^{\mathrm{a}}$ & $3022.8 \pm 257.3^{b}$ \\
\hline 2 & ${ }^{\mathrm{B}} 0.06 \pm 0.004^{\mathrm{a}}$ & ${ }^{\mathrm{A}} 4.47 \pm 0.06^{\mathrm{b}}$ & ${ }^{\mathrm{B}} 9.1 \pm 1.0^{\mathrm{ab}}$ & $3557.0 \pm 107.8^{\mathrm{a}}$ \\
\hline 3 & ${ }^{\mathrm{B}} 0.08 \pm 0.003^{\mathrm{a}}$ & $4.19 \pm 0.02^{\mathrm{c}}$ & ${ }^{\mathrm{B}} 11 \pm 1.6^{\mathrm{b}}$ & $3074.9 \pm 85.0^{\mathrm{b}}$ \\
\hline 4 & ${ }^{\mathrm{B}} 0.1 \pm 0.005^{\mathrm{b}}$ & ${ }^{\mathrm{A}} 4.11 \pm 0.03^{\mathrm{c}}$ & ${ }^{\mathrm{B}} 13 \pm 0.7^{\mathrm{b}}$ & $3647.0 \pm 281.0^{\mathrm{a}}$ \\
\hline \multicolumn{5}{|c|}{ November (autumn) } \\
\hline 1 & ${ }^{\mathrm{A}} 0.03 \pm 0.004$ & ${ }^{\mathrm{B}} 4.89 \pm 0.19^{\mathrm{a}}$ & $7.0 \pm 0.1$ & ${ }^{\mathrm{A}} 1426.5 \pm 159.5^{\mathrm{b}}$ \\
\hline 2 & ${ }^{\mathrm{A}} 0.03 \pm 0.002$ & ${ }^{\mathrm{B}} 4.71 \pm 0.01^{\mathrm{b}}$ & ${ }^{\mathrm{A}} 6.3 \pm 0.3$ & ${ }^{\mathrm{A}} 1663.2 \pm 208.6^{\mathrm{b}}$ \\
\hline 3 & ${ }^{\mathrm{A}} 0.04 \pm 0.004$ & $4.33 \pm 0.01^{\mathrm{c}}$ & ${ }^{\mathrm{A}} 7.1 \pm 0.2$ & $2729.6 \pm 248.4^{\mathrm{a}}$ \\
\hline 4 & ${ }^{\mathrm{A}} 0.049 \pm 0.003$ & ${ }^{\mathrm{B}} 4.24 \pm 0.02^{\mathrm{c}}$ & ${ }^{\mathrm{A}} 7.8 \pm 0.2$ & $3053.2 \pm 248.6^{\mathrm{a}}$ \\
\hline
\end{tabular}

${ }^{a}$ Fresh weight $(\mathrm{FW})$ of noni fruit. Values are given as mean of three independent sampling each one with three replicates in triplicates $(\mathrm{n}=9)( \pm \mathrm{SD})$. Means with different lower case letters in the same column indicate significant differences between ripening stages in the same season at $\mathrm{P}<0.05$ by TukeyKramer test. Means with different capital letter in the same column are significantly different in the same maturity stage but in different season at $\mathrm{P}<0.05$, Tukey -Kramer test.

The process of ripening of the fruit associated to high temperature cause changes in the permeability of the cell membranes [10]. The change in ripeness from stage 4 to stage 5 occurs very quickly (few hours). The pulp practically liquefies due to enzymatic activities associated with an increased availability of water in this stages allowing higher dissociation of starch, peptic solubility and increasingly hydrated pectin gel.

Stage 5 is over ripe. This stage was not included in the work because often the fruit loss its structural integrity and this could be a factor of more variability in the results. Even if this stage was evaluated in the laboratory, but this data was not incorporated to these results.

The total carbohydrates and soluble solids (SS) Table 2-3 increased during ripening of the fruit due to the greater biosynthesis of polysaccharides and their degradation to sugars. For noni fruits harvested in May- June and November the amount of carbohydrates markedly increased during fruit ripening $(\mathrm{P}<0.05)$. Fruits in advanced stages of ripening present the highest levels of sugar. In particular, at the grayishsoft ripe (stage-4) the total carbohydrates content increased. The metabolic processes associated with ripening probably entail the disassociation of some molecules and structural enzymes into soluble compounds, directly influencing the levels of total soluble solids. The correlation between ${ }^{\circ}$ Brix and total carbohydrates content gave significant and high $\operatorname{result}(\mathrm{Y}=0.6910 \mathrm{X}+5.1359, \mathrm{r}=0.77)$.

The highest rate of synthesis and accumulation of carbohydrates was detected during May-June; the content of total sugars in noni fruits increases significantly in approximately $50 \%$ during complete ripening. The high temperature in this period is likely responsible for the fact that sugar content of ripe fruit is significantly higher $(\mathrm{P}<0.05)$ than in other seasons. The lowest total carbohydrates content were found in early maturity stages during November.

Soluble solids content, expressed by ${ }^{\circ}$ Brix did not give rise to statistically significant differences among maturation stages during the coldest temperatures, only in May-June significant difference was found. In noni from Costa Rica was found soluble solid of $7.3{ }^{\circ}$ Brix [20], while in noni from Brazil was found soluble solid according to ripeness stages among 4.8 to $10.3{ }^{\circ}$ Brix [21].

The level of ascorbic acid in completely green (unripestage 1) and translucent- grayish (ripe-stage 4) is $100 \mathrm{mg}$ and $182 \mathrm{mg}$ for each $100 \mathrm{~g} \mathrm{FW}$, respectively. During the ripening, the vitamin $\mathrm{C}$ increased (table 2). The level was found significantly different between green, yellow and grayish fruit. Ripe fruit had the highest level of ascorbic acid, while green noni had the lowest. The content in fruits harvested in May-June (hottest temperatures) was found to be very high, while in November was significantly lower $(\mathrm{P}<0.05)$. This may be due to the fact that the activity of the plants is at its maximum during hot seasons (May-June in Mexico). However, this activity reduces with the decrease in seasonal temperature resulting in a lower content, mainly in middle stages.

Longer day lengths and higher light intensities in summer months can increase the concentrations of glucose (the precursor to ascorbic acid); temperature also influences vitamin $\mathrm{C}$ content [22]. Good and significant correlations between ascorbic acid content and SS $(\mathrm{r}=0.73 ; \mathrm{P}<0.01)$, and total carbohydrates $(\mathrm{r}=0.64 ; \mathrm{P}<0.01)$ were obtained during ripening at different seasons.

The value of ascorbic acid found in ripe soft fruit is comparable to noni fruits from Guam Pacific island [23] $(173.7 \mathrm{mg} / 100 \mathrm{~g})$; however, this work reported that the ripe soft fruit exhibited less ascorbic acid content than white hard fruits. The literature reports that the vitamin $\mathrm{C}$ content of fresh noni varies from 32 to $316 \mathrm{mg} / 100 \mathrm{~g} \mathrm{FW}$. The different values may be due to different cultivars, different extraction methods, and the methods of expressing the results. In our study the ripe soft fruits were found to exhibit much higher value in ascorbic acid than immature 
green and sub-mature fruit in all season's patterns. Noni represents an important source of vitamin $\mathrm{C}$ for human consumption, presenting values of $182 \mathrm{mg} 100 \mathrm{~g}^{-1}$, higher than these of mango $\left(60.5 \mathrm{mg} 100 \mathrm{~g}^{-1}\right)$, papaya (92.9 mg100 $\left.\mathrm{g}^{-1}\right)$ and in range of guava (174.2-396.7 mg100 $\left.\mathrm{g}^{-}\right)$[24].

The ash content ranged between 0.79 and $1.34 \mathrm{~g} / 100 \mathrm{~g}$ FW. Ash showed values in good agreement with the literature: $8.4 \%$ of the dry matter mainly potassium; sulfur, calcium, phosphorus and traces of selenium have been reported in the juice [7]. No significant differences during the fruit development and time of harvest were detected (table 2). However had significant maturity stages $\mathrm{x}$ season interaction $\left(\mathrm{P}=0.006^{*}\right)$. A trend to lower ash content was noted in November.

Generally, ripening fruit presented higher protein values $(\mathrm{P}<0.05)$ than immature ones, except in May-June. This period also showed much higher protein than FebruaryMarch and November. In this harvest time, the protein content was about $50 \%$ greater during early maturity than in other seasons, presumably indicating that high temperature increases the metabolic reactions that involve the synthesis of proteins, enzymes, and pigments. The fruit protein content is surprisingly high, representing $11.3 \%$ of the juice dry matter, and the main amino acids are aspartic acid, glutamic acid and isoleucine [7].

The amount of total titratable acidity (TA) in the present study (table 3) ranged from $0.029 \mathrm{~g}$ malic acid/100 mL (stage1-November) to $0.186 \mathrm{~g}$ malic acid/100 mL (stage-4 February-March). Remarkable significance differences were observed among unripe fruit and completely ripe fruit, where total acidity content was found almost 2 -fold higher in full ripe compared to early maturity stage. This increase was statistically significant $(\mathrm{P}<0.05)$ for the fruit harvested in February-March and May-June.

November had the lowest level $(\mathrm{P}<0.05)$ of total acidity of all growing seasons, and no significant differences were found during fruit development. Silva et al. [21] reported the same behavior when they studied noni fruits from Brazil. Although TA in this fruit (0.21-0.39\% citric acid) reported was higher than the values found in this work.

The production of organic acids during ripening reduces the $\mathrm{pH}$. Considering $\mathrm{pH}$ (table 3 ), the fruits can be classified as acid. The $\mathrm{pH}$ of completely ripe fruit was significantly lower than in totally green fruit. Although the $\mathrm{pH}$ decreased significantly respect to ripeness, this change was not remarkable as the increase of total acidity. The correlation between them was found acceptable $(\mathrm{r}=-0.52 ; \mathrm{P}$ $<0.01$ ). The effect of different climate conditions seems to be very important. Noni at different maturation stages produced in November had the lowest acidity in comparison to other seasons.

Total phenolic content in Noni differed (1426.5- 3647.0 $\mu \mathrm{g} \mathrm{GAE} / \mathrm{g} \mathrm{FW}$ (table 3 ) between ripeness stage and season. In February-March and May-June, phenolic increased during early development, decreased by the sub-mature stage, and increased again until maturation. In addition, the total content of phenolics changed in an irregular form.
These findings agree in part with the results reported by Yang et al. [23], in noni from Guam Pacific island, which reported that total phenol in sub-mature white hard fruit (284.8 mg AGE/100 g) was 1.3 times greater than that of ripe fruits (225.3 $\mathrm{mg} \mathrm{AGE} / 100 \mathrm{~g})$.

Our research showed that ripe fruit (stage 4) of all season had higher phenolic levels than immature ones. Winterspring and spring-summer translucent- grayish and soft fruit (stage 4) showed the highest level of phenolic. In all season patterns, totally green noni (stage 1) presented the lowest phenolic content. Polyphenol contents of unripe fruit (stages 1-2) collected in November were significantly lower than the unripe fruit in other seasons. Nevertheless, November ripe fruit was comparable with others seasons ripe fruit. Chan-Blanco et al. [25] reported total phenols levels of 41 and $51 \mathrm{mg} \mathrm{AGE/100} \mathrm{g} \mathrm{for} \mathrm{unripe} \mathrm{and} \mathrm{ripe} \mathrm{noni,}$ respectively, cultivated in Costa Rica. However, phenol contents detected in our research were much greater than those. Folin -Ciocalteu assay may over-estimates the content of phenolic due to the interference from other reducing agents present in food (i.e. ascorbic acid) in this paper.

Other fruits and vegetables also show different levels of total phenol and ascorbic acid content at different stages of maturation. For example, ripening increases the ascorbic acid and total phenols content of sweet cherry [26], but decreases total phenol of blueberry [27] and red pepper [28] and decreases the ascorbic acid content of Rubus coreanus fruit [29].

When comparing the chromatogram of noni with the mixture of standards (gallic acid, catechin, rutin, quercetin and scopoletin) (Figure 1), small peaks can be seen of catechin, rutin and scopoletin, but not for gallic acid and quercetin. Additionally the chromatogram depicts two major signals unknown, one at 30 minutes of retention (X) and other at 50 minutes (Y) (Figure 2). The content of phenolic compounds changed during fruit development; catechin and rutin levels varied notably, whereas scopoletin content was more stable.

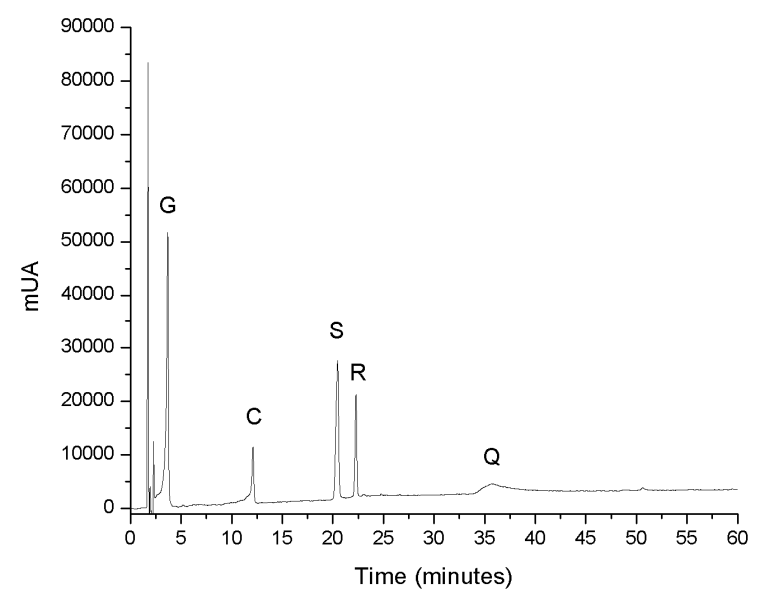

Figure 1. Cromatographic profile of five reference stardard compounds; $G=$ gallic acid, $C=$ Catechin; $S=$ Scopoletin; $R=$ Rutin and $Q=$ Quercetin measured at $280 \mathrm{~nm}$. 


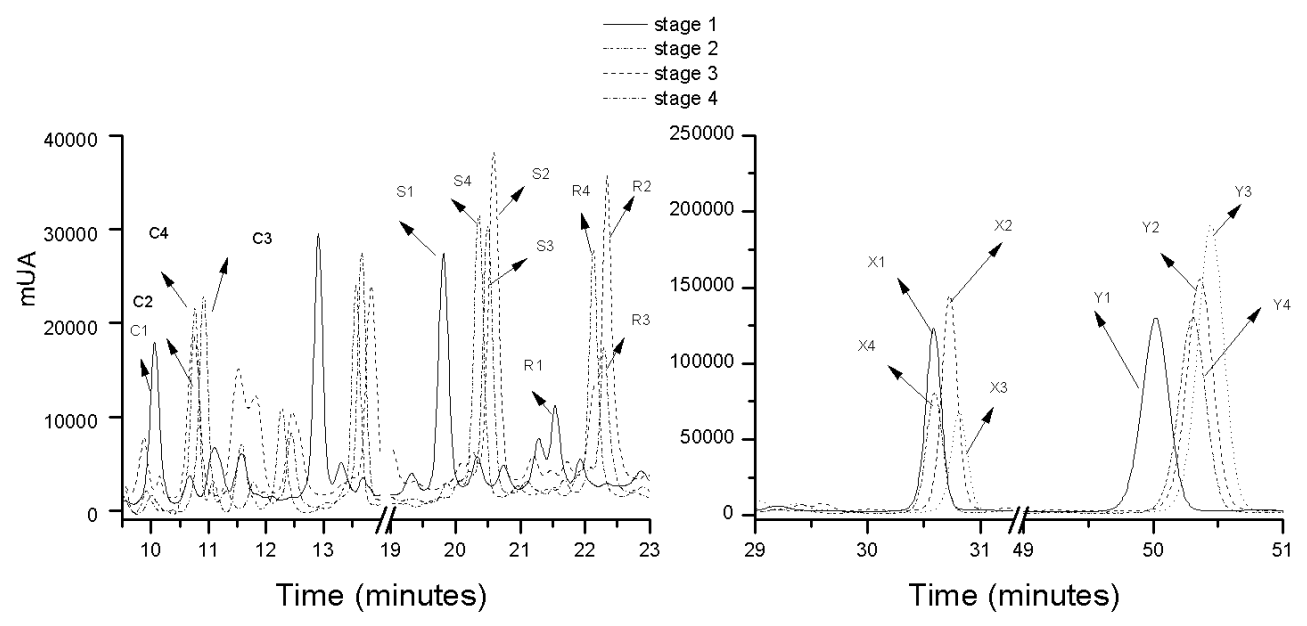

Figure 2. HPLC chromatograms of phenolic compouds at various stages of maturity in February and March: C1) catechin stage 1; C2) catechin stage 2; C3) catechin stage 3 and C4) catechin stage. S1) scopoletin stage 1; S2) scopoletin stage 2; S3) scopoletin stage 3 and S4) scopoletin stage 4. R1) rutin stage 1 ; $R 2$ ) rutin stage $2 ; R 3)$ rutin stage 3 and $R 4$ ) rutin stage 4

Content of polyphenols: catechin, scopoletin and rutin during the fruit development and year seasons are listed in table 4. Scopoletin is one of the most important compounds in noni juice. The concentration of scopoletin ranged from $24.26 \mu \mathrm{g} / \mathrm{g}$ (stage 2- May-June) to $65.16 \mu \mathrm{g} / \mathrm{g}$ (stage 4 November), no significant differences in ripeness-stage were found. In ripe noni fruit, scopoletin content tends to be slightly higher than unripe fruit, as reported [30] in noni juice during fermentation. During May-June, scopoletin levels were significantly the lowest $(\mathrm{P}<0.05)$ of all maturity stage compared to coldest seasons. Catechin values remained fairly constant with no statistical difference among the first maturity (stages 1-3). The highest amount of catechin was detected at the grayish-ripe stage in all the studied seasons. The amount of catechin does not appear to be influenced by the growing season, with the exception for stage 2 during February-March and May-June. Rutin content was highest in middle stage (stage 2) and complete maturity (stage 4), and correlates powerfully with total phenolic content (Table 3). Our study found average values $(\mu \mathrm{g} / \mathrm{g})$ for catechin, scopoletin and rutin similar between February-March and November. In May-June, catechin and scopoletin were presented in relatively low amounts, whereas rutin content was relatively high. This fact could indicate that phenolic compounds vary with season patterns.

Table 4. Phenolic contents ( $\mu \mathrm{g} / \mathrm{g}$ fresh weight) at different stages of development and seasons harvest in Morinda citrifolia

\begin{tabular}{|c|c|c|c|c|c|}
\hline \multirow{2}{*}{ Compound } & \multicolumn{4}{|l|}{ Stages of maturity } & \multirow[b]{2}{*}{ Average } \\
\hline & 1 & 2 & 3 & 4 & \\
\hline & February - March & & & & \\
\hline Catechin & $36.88 \pm 6.1^{\mathrm{b}}$ & ${ }^{\mathrm{B}} 48.34 \pm 3.9^{\mathrm{a}}$ & $33.73 \pm 2.3^{\mathrm{b}}$ & $42.67 \pm 4.9^{\mathrm{a}}$ & $40.41 \pm 6.46$ \\
\hline Scopoletin & ${ }^{\mathrm{AB}} 38.47 \pm 7.1$ & ${ }^{\mathrm{c}} 58.47 \pm 7.1$ & ${ }^{\mathrm{B}} 51.21 \pm 1.2$ & ${ }^{\mathrm{A}} 45.76 \pm 8.1$ & $48.88 \pm 8.47$ \\
\hline \multirow[t]{2}{*}{ Rutin } & ${ }^{\mathrm{A}} 25.95 \pm 4.0^{\mathrm{a}}$ & $69.88 \pm 14.4^{b}$ & $43.20 \pm 5.2^{\mathrm{ab}}$ & $72.98 \pm 11.1^{\mathrm{b}}$ & $53.00 \pm 22.45$ \\
\hline & May- June & & & & \\
\hline Catechin & $26.16 \pm 2.2^{\mathrm{a}}$ & ${ }^{\mathrm{A}} 28.15 \pm 1.3^{\mathrm{ab}}$ & $35.65 \pm 5.4^{\mathrm{ab}}$ & $45.47 \pm 2.4^{\mathrm{b}}$ & $33.94 \pm 8.69$ \\
\hline Scopoletin & ${ }^{\mathrm{A}} 26.67 \pm 6.0$ & ${ }^{\mathrm{A}} 24.26 \pm 2.2$ & ${ }^{\mathrm{A}} 25.03 \pm 3.8$ & ${ }^{\mathrm{A}} 31.67 \pm 0.7$ & $26.91 \pm 3.33$ \\
\hline \multirow[t]{2}{*}{ Rutin } & ${ }^{\mathrm{B}} 109.9 \pm 24.6^{\mathrm{a}}$ & $37.07 \pm 0.4^{\mathrm{bc}}$ & $28.70 \pm 6.2^{c}$ & $65.22 \pm 13.9^{b}$ & $60.35 \pm 36.38$ \\
\hline & November & & & & \\
\hline Catechin & $38.58 \pm 0.7^{\mathrm{a}}$ & ${ }^{\mathrm{AB}} 39.13 \pm 7.8^{\mathrm{a}}$ & $38.18 \pm 4.1^{\mathrm{a}}$ & $53.18 \pm 3.9^{b}$ & $42.27 \pm 7.29$ \\
\hline Scopoletin & ${ }^{\mathrm{B}} 55.65 \pm 8.8$ & ${ }^{\mathrm{B}} 43.52 \pm 0.6$ & ${ }^{\mathrm{AB}} 47.54 \pm 6.6$ & ${ }^{\mathrm{B}} 65.16 \pm 5.4$ & $52.97 \pm 9.57$ \\
\hline Rutin & ${ }^{\mathrm{A}} 29.86 \pm 0.6^{\mathrm{a}}$ & $59.28 \mathrm{a} \pm 1.9^{\mathrm{b}}$ & $35.29 \pm 5.3^{\mathrm{a}}$ & $81.34 \pm 7.6^{b}$ & $51.44 \pm 23.68$ \\
\hline
\end{tabular}

Values are given as mean of three independent sampling each one with three replicates in triplicates $(n=9)( \pm S D)$. Means with different lower case letters in the same row indicate significant differences between maturity stages in the same season $(\mathrm{P}<0.05$, Tukey- Kramer Multiple Comparison test). Means with different capital letter are significant differences in the same maturity stage but different season at $\mathrm{P}<0.05$, by Tukey- Kramer Multiple Comparison test.

Rutin and scopoletin levels can be considered high compared to the results of total phenol and phenolic compounds contained in noni grown in Costa Rica [25]: rutin $(6.06 \mu \mathrm{g} / \mathrm{g} \mathrm{FW})$, scopoletin $(27.9 \mu \mathrm{g} / \mathrm{g} \mathrm{FW})$. We found 10 times more rutin content than those; for scopoletin we obtained values similar in May-June. Differences can be associated with environmental conditions, as well as other growing practices. Our results are comparable with the results reported by [31]: rutin $(60.23 \mathrm{mg} / \mathrm{kg} \mathrm{FW})$.

During ripening generally the highest amounts of soluble protein, total carbohydrates, soluble solids, ascorbic acid and total phenols were reached at the grayish-soft fruit 
(stage-4). A significant increase of these quantities was more marked during May-June (hot months). Although fully ripe fruit had the maximum value of polyphenols during middle stage (stage 2) was found high content of total phenolics and flavonoid. Hence, the increase of total phenolic during noni fruit ripening depends on their maturity stages.

Significant differences $(\mathrm{P}<0.05)$ in soluble solids, total carbohydrates, protein, ascorbic acid and total phenolic as a function of the season were as: spring-summer $>$ winterspring $>$ autumn. The same trend of seasonal effect on ash and rutin was observed. The activity of the plants is at its maximum during hot seasons (May-June in Mexico), leading to highest nutritional value and bioactive compounds.

Furthermore the content of total phenolic increased 2fold from immature stages in May-June (highest light intensity: $1182.9 \mu \mathrm{molm}^{-2} \mathrm{~s}^{-1}$ ) respect to November (lowest light intensity: $\left.982.2 \mu \mathrm{molm}^{-2} \mathrm{~s}^{-1}\right)$. Generally polyphenols are influenced by the solar radiation exposure, which may be associated with free radical formation and singlet oxygen production for a self-defense system.

Marked variation in the behavior of $\mathrm{pH}$, moisture, catechin and scopoletin as a function of the season tends as: autumn $>$ winter-spring $>$ spring-summer, although results for phenolic compounds were statically non-significant among season.

\section{Conclusions}

Our data highlight the important role played of maturity stages and harvest season on chemical composition and phenolic content of noni fruits. The amount of moisture, soluble protein, total carbohydrates, soluble solids, ascorbic acid and total acidity increased with ripening. Remarkable differences were found among totally immature and full ripe, wherefore fruit ripening in different stage affected the total phenols and flavonoids contents. Higher amount of total phenols, catechin and rutin of full-ripe stage were observed in all harvest seasons. Scopoletin content was not significantly affected by ripeness, whereas harvest seasons affected the quantities in all maturity stages. The study of changes in nutritional and bioactive compounds during ripening is of great relevance both to human health and commercial purposes. The results obtained allow us to suggest that better harvesting period to reach the highest nutritional and antioxidant potential was spring-summer $>$ winter-spring $>$ autumn. These data are useful to define the production system of this crop and maximize the health benefits and commercial purpose. More studies about phenolic profiles along ripening and their influence on antioxidant properties should be carried out in order to elucidate the main sources of quality of ripe noni fruits.

\section{Acknowledgement}

The authors would like to thank the National Council of
Science and Technology of Mexico (CONACYT) for financing the project. The language corrections assistance of Mark F. MCcarty Ph.D is greatly appreciated.

\section{References}

[1] Nelson SC (2003). Noni cultivation and Production in Hawaii. In: Proceedings of the 2002 Hawaii Noni Conference. University of Hawaii at Nanoa. College of Tropical Agriculture and Human Resources. Hawaii.

[2] Ross IA (2001). Medical Plants of the World. Chemical Constituents, Traditional and Modern Medical Uses. Humana Press, New Jersey.

[3] Furusawa E, Hirazumi A, Story S, and Jenson J (2003). Antitumor potential of polysaccharide-rich substance from the fruit juice of Morinda citrifolia (noni) on sarcoma 180 ascites tumour in mice. Phytother Res., 17, 1158-1164.

[4] Su BN, Pawlus AD, Jung HA, Keller WJ, McLaughlin JL, and Kinghorn AD (2005). Chemical constituents of the fruits of Morinda citrifolia (noni) and their antioxidante activity. J. Nat. Prod., 68: 592-595.

[5] Wang M and Su C, (2001). Cancer preventive effect of Morinda citrifolia (Noni). Annals of the New York Academy of Sciences 952, 161-168.

[6] Morton JF (1992). The ocean-going Noni, or Indian mulberry (Morinda citrifolia, Rubiaceae) and some of its "colourful" relatives. Econ. Botany 46: 241-256.

[7] Chunhieng MT (2003). Developpement de nouveaux aliments santé tropicale: application a la moix du Bresil Bertholettia excelsa et au fruit de Cambodge Morinda citrifolia. Ph.D thesis, INOL, France.

[8] Shovic AC and Whistler WA (2001). Food sources of provitamin A and vitamin $\mathrm{C}$ in the American Pacific. Tropical Sci. 41: 199-202.

[9] Farine JP, Legal L, Moreteau B, LeQuere JL (1996). Volatile components of ripe fruits of Morinda citrifolia and their effects on Drosophila. Phytochemistry 41, 433-438.

[10] Antoniali S, Ademar P, Magalhaes, AM, Tsuyoshi R, Sanchez (2007). J., Physico-Chemical characterization oz Zarco HS yellow Bell pepper for different ripenesess stage. Sci. Agric. 64 (1): 19-22.

[11] Liu Ch, Xue Y, Ye Y, Yuan F, Liu J and Shuang J (2007). Extraction and characterization of antioxidant compositions from Fermented fruit juice of Morinda citrifolia (Noni). Agric. Sci. in China. 6(12): 101-105.

[12] Secretaria de Agricultura, Ganadería, Desarrollo Rural, Pesca y Alimentación SAGARPA (2010)-Servicio de Información Agroalimentaria y Pesquera (SIAP). Retrieved February 2012, from: http:www.siap.gob.mx.

[13] Sistema Estatal de Monitoreo Agro-Climático (SEMAC), Nayarit. 2010. Retrieved February 2010, from: http : www.climanayarit.gob.mx

[14] ASSOCIATION OF OFFICIAL ANALYTICAL CHEMISTRY. AOAC (2005). Official methods of analysis of the Association of Official Analytical Chemistry. 18 th Ed. 
[15] Dubois M. Gilles KA, Hamilton JK, Rebers PA. and Smith F (1956). Colorimetric Method for Determination of Sugars and Related Substances. Anal.Chem., 28(3):350-356.

[16] Lowry OH, Rosenbroug NJ, Farr AL, Randal R (1951). Protein measurement with the Folin phenol reagent, J. Biol. Chem., 193: 265-275.

[17] Doner LW \& Hicks KB (1981). High-performance liquid chromatographic separation of ascorbic acid, erythorbic acid, dehydroascorbic acid, dehydroerythorbic acid, diketogulonic acid and diketogluconic acid. Anal. Biochem., 115: 225-230.

[18] Singleton, VL and Rossi JA (1965). Colorimetry of Total Phenolics with Phosphomolybdic-Phosphotungstic Acid Reagents. Amer. J. Enol. and Vitic., 16: 144-158.

[19] Rodríguez-Delgado MA, Malovana S, Perez JP, Borges T and García Montelongo FJ (2001). Separation of phenolic compounds by high-performance liquid chromatography with absorbance and fluorimetric detection. $J$. of Chromatography A. 912: 249-257.

[20] Chan-Blanco Y, Vaillant F, Perez AM, Reynes M, Brillouet JM, Brat P, (2006). The noni fruit (Morinda citrifolia L.): A Review of agricultural research, nutritional and therapeutic properties. J. Food Compos. Anal., 19: 645-654.

[21] Silva LRD, Medeiros PV, Leite GA Silva KJ, Mendoca V (2008). Caracterização físico-química do fruto de Noni (Morinda citrifolia L.). Revista Brasilera de Frutucultura, Jaboticabal, 25: 335-347.

[22] Lee SK, Kader AA, 2000. Preharvest and postharvest factors influencing vitamin $\mathrm{C}$ content of horticultural crops. Postharv. Biol. and Technol.20: 207-220.

[23] Yang J, Gadi R and Thompson T (2011). Antioxidant capacity, total phenols, and ascorbic acid content of noni (Morinda citrifolia) fruits and leaves at various stages of maturity. Micronesica, 41(2): 167-176.
[24] Thaipong K, Boonprakob U, Crosby K, Cisneros-Zevallos L and Hawkins D (2006). Comparison of ABST, DPPH, FRAP, and ORAC assays for estimating antioxidant activity from guava fruit extracts. J. Food Compos. and Ana., 19: 669-675.

[25] Chan-Blanco Y, Vaillart F, Pérez AM, Brat P (2007). In Colon Wilfredo (ed), Lugo Wanda I. (ed). Marketing opportunities for agricultural and forestry products in the Greater Caribbean - A challenge for the 21 st century. San Juan: Caribbean Food Crops Society, p 151. URL: $<$ http:77cfs.eea.uprm.edu/43\%20meeting.htm.

[26] Serrano M, Guillen F, Martínez-Romero D, Castillo S, Valero D (2005). Chemical constituents and antioxidant activity of sweet cherry at different ripening stages. J. Agric. and Food Chem. 53: 2741-5.

[27] Castrejon ADR, Eichholz I, Rohn S, Kroh LW, S HuyskensKeil. (2008). Phenolic profile and antioxidant activity of highbush blueberry (Vaccinium corymbosum L.) during fruit maturation and ripening. Food Chem., 109: 564-72.

[28] Zhang D and Hamauzu Y, (2003) Phenolic compounds, ascorbic acid, carotenoids and antioxidant properties of green, red and yellow bell peppers. Food, Agric. \& Envir. l(2): 22-27.

[29] Park Y, Kim SH, Choi SH, Han J, Chung HG (2008). Changes of antioxidant capacity, total phenolics, and vitamin $\mathrm{C}$ content during Rubus coreanus fruit ripening. Food Sci. and Biotech. 17: 251-6.

[30] Yang S, Chen T, Li K And Tsai T (2007). Change in phenolic compound content, reductive capacity and ACE inhibitory activity in noni juice during traditional fermentation. J. Food and Drug Ana., 15(3): 290-298.

[31] Muñoz Jáuregui AM, Ramos-Escudero F, Alvarado-Ortiz C y Castañeda-Castañeda B (2007). Evaluación de la capacidad antioxidante y contenido de compuestos fenólicos en recursos vegetales promisorios. Rev. Soc. Quím. Perú. 73(3): 142-149. 